\title{
A educação e o prólogo da Genealogia da Moral de Nietzsche
}

\section{Resumo}

A partir de uma análise da estrutura do "Prólogo" da Genealogia da Moral de Friederich Nietzsche, este trabalho pretende compreender como este filósofo concebe a forma pela qual ele mesmo esteve, desde a infância, diante dos questionamentos sobre a origem dos valores morais. Tal esforço tem por fim entender em que medida é possível aproveitarmos essa experiência de Nietzsche para definirmos uma tarefa para a pedagogia, qual seja, a de questionar os valores morais existentes em seu interior. Todavia, bem menos do que definir propriamente esta tarefa para a pedagogia, este trabalho deve consistir - em função de suas pequenas ambições - em um esboço inicial da questão.

Palavras-chave: Nietzsche, Friederich (1844-1900); Filosofia da Educação; Genealogia da Moral.

\section{Abstract}

From an analisys of the prolegomenon to On the Genealogy of Morals of Friederich Nietzche, this work intents to comprehend how this philosopher conceives his own position, since his childhood, before the questions about the source of the moral values. Such effort has the purpose to understand how it is possible to make good use of this experience of Nietzsche to define a task for the pedagogy, that means, the questing about the moral values existent inside it. Nevertheless, less than defining properly this task for the pedagogy, this work shall build - due to its small ambitions - an initial sketch for the question.

Keywords: Nietzsche, Friederich (1844-1900); Philosophy of Education; On the Genealogy of Morals 


\section{Introdução: Nietzsche e o problema da interpretação ${ }^{1}$}

Genealogia da Moral ${ }^{2}$ de Friederich Nietzsche, obra composta
por um "Prólogo" e três dissertações subseqüentes, pode ser to-
mada, em muitas de suas nuances, como uma investigação acompanhada de uma análise, em que, de forma extremamente peculiar, a análise se torna mais interessante e valiosa que a investigação. Embora o substrato do qual parte Nietzsche para construir suas análises também surpreenda, é certamente enquanto análise que, na perspectiva do homem contemporâneo imerso nas questões de seu tempo, o livro notadamente alcança seu ponto mais alto. A análise torna-se criação e, enquanto criação, possui uma certa estética que exige, em boa medida, que se caia no jogo do autor, isto é, que não se o observe com os olhos de quem ele critica, ou seja, com os olhos do sujeito moderno paralisado, por exemplo, diante de questões hermenêuticas infrutíferas.

O rigor de Nietzsche, que é a todo o momento solicitado por ele ao seu leitor, é o "rigor da vaca", o rigor daquele que perpassa lentamente vários dias diante de sua obra, ruminando-a em silêncio. Ele não escreve para aqueles a quem critica com a ambição de refutá-los ${ }^{3}$, nem sequer pretende oferecer-lhes uma resposta, mas escreve para aquele que se abre e se dispõe a entender que lê-lo verdadeiramente é uma questão de abrir-se. Nietzsche não coloca à disposição um "Vademecum", mas oferece, em uma rima de

\footnotetext{
${ }^{1}$ A citação das obras de Nietzsche dar-se-á da seguinte maneira: Nietzsche, ano, número da página; na seqüência, para que o leitor possa consultar outras edições das mesmas obras do filósofo de forma mais objetiva, haverá o registro do nome da obra, a parte/dissertação/capítulo e o número do item/aforismo/parágrafo. Por exemplo: Nietzsche, 2000a, p. 155. Humano Demasiado Humano, 5, 224.

2 Não raro o leitor encontra, como tradução para título desta obra, a sentença Para uma Genealogia da Moral. Esta parece ser, inclusive, a melhor tradução, devendo o leitor compreendê-la desta maneira sempre que a referida obra for mencionada. Todavia, como o texto utilizado na pesquisa que resultou neste trabalho intitula a obra Genealogia da Moral, preferiu-se manter essa última tradução.

3 “... - que tenho eu a ver com refutações! - (Nietzsche, 1998, p. 10. Genealogia da Moral, Prólogo, 4)".

4 O "Vademecum" [literalmente: "vá comigo"] (manual ou guia de consulta para estudantes e profissionais do Direito).
}

(C) Filosofia e Educação (Online), ISSN 1984-9605 - Revista Digital do Paideia 
abertura de A Gaia Ciência, o duo "Vademecum-Vadetecum", onde afirma que seu leitor deve, antes de tudo, seguir-se, caminhando com vagar ${ }^{6}$.

Trata-se de um andamento gravíssimo cujo fim não é fixado pelo autor, mas antes pelo leitor ${ }^{7}$. Meu cuidado neste trabalho desdobra-se, portanto, em me auto-seguir a fim de levar a imagem de Nietzsche a um ponto mais claro. Quando, por outro lado, pergunto-me sobre o que eu sigo, aparece-me uma resposta imediata: a educação.

A educação aparece aqui como problema em Nietzsche, mas não viso aqui, prioritariamente, aquilo que Nietzsche expressou sobre ela, pois se eu a procurasse neste sentido, recorreria, talvez, aos seus Escritos sobre Educação. Busco este "Prólogo", e não outro fragmento da obra de Nietzsche, porque a Genealogia da Moral (publicada em 1887) é uma obra que foi sendo pensada e vivenciada por Nietzsche, segundo ele, desde os seus treze anos de idade ${ }^{8}$, tendo um primeiro esboço aos dezessete anos em um opúsculo de juventude intitulado "Fado e História"9 . Tais preocupações infantojuvenis desembocaram neste livro da maturidade, que fora escrito como “complemento e clarificação" àquela que é tida, por muitos estudiosos, como sua obra central, Além do bem e do Mal (publicada em 1886).

A Genealogia da Moral é, pois, a obra em que um problema de infância chegou aos seus extremos, e seu "Prólogo" consiste em um momento de síntese dos caminhos percorridos. Neste texto, Nietzsche deixa entrever

\footnotetext{
5 "Vademecum-Vadetecum", literalmente "Vá comigo - Vá contigo", título da referida rima (Niezsche, 2001, p. 19. A Gaia Ciência, "Brincadeira...", 7). A rima completa é a seguinte: "Atraem-lhe meu jeito e minha língua,/ Você me segue, vem atrás de mim?/ Siga apenas a si mesmo fielmente: -/ Assim me seguirá - com vagar! Com vagar!"

${ }^{6}$ A leitura calma e vagarosa é várias vezes solicitada por Nietzsche (vide a rima "Vademecum-Vadetecum" de A Gaia Ciência citada acima ou mesmo o "Prefácio" de Sobre o Futuro das Nossas Instituições de Ensino, que pode ser lido também em Nietzsche, 2000b, pp. 31-36, ou seja, no volume Cinco Prefácios para Cinco Livros não Escritos).

7 Tal é, pelo menos, o que nos sugere a leitura de outra rima da abertura de A Gaia Ciência (Nietzsche, 2001, p. 27), intitulada declaradamente "Interpretação": "Se me explico, me implico: / Não posso a mim mesmo interpretar. / Mas quem seguir sempre o seu próprio caminho / Minha imagem a uma luz mais clara também levará." Vale perceber que Nietzsche não aceita a idéia de se auto-interpretar (verso 2), pois, segundo ele, ao se explicar, estaria se implicando (verso 1). O filósofo inverte a relação "autor-condutor" e "leitorconduzido" para a relação "leitor-condutor" e "autor-conduzido", passando a ser o leitor aquele que "levará" a imagem do autor "a uma luz mais clara" (verso 4). Será o leitor, portanto, aquele que conduzirá a interpretação do autor, ele sim se auto-seguindo (verso 3).

8 Cf. Nietzsche, 1998, p. 9. Genealogia da Moral, Prólogo, 3.

9 Cf. Nietzsche, 1998, pp. 163-168. Genealogia da Moral, "Apêndice - Fado e História".
}

(C) Filosofia e Educação (Online), ISSN 1984-9605 - Revista Digital do Paideia

Volume 1, Número Especial de lançamento, Outubro de 2009 
seu processo de formação, não no sentido estrito da Bildung, mas no sentido de "processo de formulação de um problema". Interessa, então, saber qual seja a visão do próprio filósofo a respeito de seu percurso de vida, enquanto educando (o qual desde os trezes anos indaga-se sobre a moral) e quanto educador ${ }^{10}$ (que, em sua maturidade, fala de sua tarefa de preparar a humanidade para um instante de tomada de consciência suprema ${ }^{11}$, ou que convoca os homens a um esforço de reeducação do gênero humano ${ }^{12}$, ou ainda que alega fazer parte da humanidade de um mestre alertar seus discípulos contra ele mesmo ${ }^{13}$ ).

Buscar a história da formulação deste problema em Nietzsche é um trabalho que, feito por outra via, conduziria a estudos mais profundos sobre a vida do filósofo alemão, seu processo de escolarização e, posteriormente, sobre sua atividade docente. Não é a isso que este texto se propõe, pois ingressar na investigação destas questões significaria desviar-se de outra pesquisa mais interessante e que já fora expressa: abordar a visão do próprio Nietzsche a respeito de seu processo de formulação da pergunta sobre a origem dos valores morais.

A que visa um tal estudo? Este estudo possui ambições pequenas, pelo menos a princípio: compreender como se deu, segundo o próprio $\mathrm{Ni}$ etzsche, seu processo de formulação da questão sobre a origem dos preconceitos morais e como é possível esboçar, a partir do próprio Nietzsche, a definição de uma tarefa para a pedagogia, qual seja, a de perguntar-se sobre a origem dos preconceitos morais existentes em seu interior.

\section{A estrutura do "Prólogo" da Genealogia da Moral}

Com esta apresentação da estrutura geral e análise do "Prólogo" da Genealogia da Moral, não se pretende esgotar o texto nietzscheano em

\footnotetext{
10 Cf. Dias (1991), em seu livro Nietzsche Educador, principalmente das páginas 51-57, em que a autora dispõe alguns depoimentos de ex-alunos de Nietzsche comentando o desempenho didático do mestre.

11 Nietzsche, 1995, p. 79. Ecce Homo, "Aurora: Pensamentos sobre a Moral como Preconceito", 2.

12 Nietzsche, 2004, p. 21. Aurora, 1, 13.

13 Nietzsche, 2004, p. 231. Aurora, 5, 447.
} 
questão; visa-se apenas deixar o leitor a par do texto sobre o qual será feita a interpretação. Toma-se, pois, este "Prólogo" não só como prólogo de uma obra específica, da qual - sem dúvida - ele o é, mas, sobretudo, como uma fonte que permita partir em busca de outras obras de Nietzsche, além da Genealogia da Moral.

O "Prólogo" desta obra está dividido em oito itens inominados, os quais este estudo passará imediatamente a apresentar. O primeiro deles consiste, de certo modo, em uma introdução geral a qualquer estudo sobre a genealogia da moral; o tema central deste item é, pois, o conhecimento do homem pelo próprio homem; o segundo item consiste, por sua vez, em uma introdução geral à presença de idéias sobre a moral no próprio Nietzsche; o terceiro revela a passagem nietzscheana do preceito teológico ao preceito moral, apresentando a primeira ruptura do pensamento moral em Nietzsche; o quarto item indica qual foi o primeiro impulso do filósofo alemão à apresentação de suas idéias concernentes à moral, qual seja, a publicação, em 1877, do livro de Paul Rée intitulado Sobre a Origem das Nossas Impressões Morais; no quinto tópico, Nietzsche apresenta qual era sua real preocupação desde então: o valor da moral e, especificamente, alguns valores como o de não-egoísmo e instintos como os de compaixão, abnegação, sacrifício, entre outros; o sexto, por seu turno, partindo da constatação de que os problemas sobre o valor da compaixão e a moral da compaixão não são isolados, finda por estabelecer uma exigência muito mais ampla: a necessidade de uma crítica dos valores morais em que o próprio valor desses valores seja colocado em questão; o sétimo é aquele em que, como nos antigos textos filosóficos, o autor apresenta seu "método", neste caso, o "método genealógico" 14 ; o oitavo item encerra o "Prólogo" com considerações sobre a leitura do livro que está na iminência de se iniciar e as dificuldades interpretativas que acompanham a leitura dos demais livros do autor.

O primeiro item é aberto por Nietzsche com a seguinte afirmação: os homens do conhecimento desconhecem a si mesmo, uma vez que nunca se procuraram e, sendo assim, jamais se encontrariam. Na seqüência, Ni-

\footnotetext{
14 As aspas sobre método e método genealógico têm por finalidade indicar que Nietzsche, ao menos neste "Prólogo", não considerou literalmente a genealogia como um método. A idéia de "método" foi, portanto, inserida por conta deste estudo.
} 
etzsche dá razão a Jesus Cristo (a quem chama de "alguém"), quando repete sua frase proferida no "Sermão da Montanha": "Onde estiver teu tesouro, estará também teu coração". Nesta frase, o filósofo afirma que o tesouro está no mesmo lugar em que estão as colméias do nosso conhecimento e que os homens estão sempre a caminho delas, tendo um único objetivo: levar algo para casa.

Nietzsche prossegue o primeiro item denunciando a falta de tempo dos homens para as vivências, não as levando a sério; os homens, segundo o filósofo, estão sempre ausentes das experiências do presente, deixando de ter ali seu coração ou seus ouvidos.

Os homens são, segundo o filósofo, seres dispersos divinamente e imersos em si, os quais despertam ao ouvir as doze batidas do meio-dia, perguntando a si mesmos não só o que soou, mas também o que foi que viveram. Ao contarem, depois, as batidas, contam-nas erradamente, pois continuam estranhos a si mesmos, sem qualquer compreensão. A esta altura, Nietzsche inverte a afirmação de Terêncio ${ }^{15}$, dizendo: cada um é o mais distante de si mesmo. Este item se encerra no mesmo tom em que começou, alegando que relativamente aos homens, os homens são homens do desconhecimento.

O segundo item do "Prólogo", que revela uma determinada introdução geral à presença das idéias sobre a moral em Nietzsche, inicia-se justamente com uma referência ao livro Humano Demasiado Humano, o qual na visão do próprio autor apresentada neste "Prólogo" - possui uma primeira expressão (modesta e provisória) dos seus pensamentos sobre a origem dos nossos preconceitos morais. Redigida num momento de parada, como aquela que faz um andarilho, tal obra permitiu a Nietzsche deitar os olhos sobre a vasta e perigosa terra que ele percorreu com seu espírito. Os pensamentos expostos em Humano Demasiado Humano, afirma o filósofo, já eram antigos e são os mesmos que lhe ocupam precisamente nesta época de

15 Publius Terentius Afer, mais conhecido como Terêncio (185-159 a.C.), escreveu diversas comédias no período da República Romana. 
redação da Genealogia da Moral ${ }^{16}$. Sua insistência de maneira muito firme nestes pensamentos, segundo observa o filósofo alemão, reafirma nele a confiança feliz de que tais reflexões não se formaram de modo fortuito e isolado, mas a partir de uma raiz comum, algo que "comanda na profunde$\mathrm{za}{ }^{17}$, isto é, uma vontade fundamental de conhecimento, expressa cada vez com maior determinação e exigindo a cada momento uma precisão maior, como é conveniente a um filósofo. Ao contrário, diz Nietzsche, as idéias, os valores, os sins, os nãos, ses e os quês nascem nos filósofos com a mesma necessidade que a árvore tem de seus frutos: todos estão inter-relacionados e são testemunhas de uma única vontade e saúde. Assim, então, o filósofo conclui: "Se vocês gostarão desses nossos frutos? Mas que importa isso às arvores! Que importa isso a nós, filósofos!...” (Nietzsche, 1998, p. 8).

No terceiro item do "Prólogo", Nietzsche considera - em primeiro lugar - seu escrúpulo relativamente a tudo que vem sendo "celebrado na terra como moral"; um tal escrúpulo que, segundo ele, é confessado a contragosto e que o habita desde muito cedo, de maneira muito insolicitada, incontida e em profunda contradição com seu ambiente, sua idade, seu exemplo e sua procedência. Este escrúpulo, de acordo com as palavras do filósofo, pode até mesmo ser considerado o seu a priori. Nesta época, precisada pelo filósofo entre os seus trezes anos, veio sua primeira questão sobre a moral: "de onde se originam verdadeiramente nosso bem e nosso mal?" (Nietzsche, 1998, p. 9, grifos do filósofo). Nietzsche descreve tal investigação como uma "primeira brincadeira literária" e um "primeiro exercício filosófico". A solução da questão que formulara, deu-se, nas próprias palavras do autor, rendendo homenagem a Deus, responsabilizando-o pela pa-

\footnotetext{
16 Nietzsche afirma, neste trecho, esperar que o intervalo entre esses pensamentos e a composição de Genealogia da Moral tenha tornado tais pensamentos, mais fortes, maduros, claros e perfeitos.

17 Esta noção de "profundeza", também é recorrente em diversas obras de Nietzsche. Todavia, seu sentido nesta passagem do "Prólogo" da Genealogia da Moral talvez se ilumine melhor com uma visita a Nietzsche, 2004, pp. 9-10. Aurora, "Prólogo", 1 e 2, quando o filósofo escreve, bem no início do livro: "Neste livro se acha um 'ser subterrâneo' a trabalhar, um ser que perfura, que escava, que solapa. Ele é visto - pressupondo que se tenha vista para esse trabalho na profundeza [...] [item 1]" "[...] desci à profundeza, penetrei no alicerce, comecei a investigar e escavar uma velha confiança, sobre a qual nós, filósofos, há alguns milênios construíamos, como se fora o mais seguro fundamento - e sempre de novo, embora todo edifício desmoronasse até hoje: eu me pus a solapar nossa confiança na moral. Estão me compreendendo? [item 2]" (grifos de Nietzsche).
}

(c) Filosofia e Educação (Online), ISSN 1984-9605 - Revista Digital do Paideia 
ternidade do mal. Nietzsche, porém, não se deu por satisfeito com esta resposta $^{18}$ e por fortuna, isto é, por sorte, ele logo aprendeu a distinguir o preconceito teológico do preconceito moral, deixando de buscar a origem do mal "por trás" do mundo. Logo (ou seja, muito em breve), alguma educação histórica e filológica, somada de um senso inato e seletivo em questões da psicologia transformou seu problema em outra formulação, desta vez mais complexa:

[...] sob que condições o homem inventou para si os juízos de valor ‘bem’ e 'mal'? e que valor têm eles? Eles obstruíram ou promoveram até agora o crescimento do homem? São indício de miséria, empobrecimento, degeneração da vida? Ou, ao contrário, revela-se neles a plenitude, a força, a vontade da vida, sua coragem, sua certeza, seu futuro? (Nietzsche, 1998, p. $9)^{19}$.

Para tais questões, Nietzsche afirma ter arriscado e encontrado diversas respostas, diferenciando "épocas, povos, hierarquia de indivíduos", especializando seu problema. Das respostas dadas, novas questões surgiam, juntamente com suposições e probabilidades. Foi assim que Nietzsche confessou já dispor de um país propriamente seu, um universo próspero, florescente. E conclui este terceiro tópico retomando, de certa forma, as colocações feitas no primeiro, ao exclamar: "Oh, como somos felizes, nós, homens do conhecimento, desde que saibamos manter silêncio por algum tempo!..." (Nietzsche, 1998, pp. 9-10)".

O quarto item, por sua vez, inicia-se com a apresentação de Nietzsche de seu primeiro impulso para divulgar suas hipóteses acerca da procedência da moral: a publicação, em 1877, do "livrinho claro, simples, limpo e sagaz - e maroto" do pensador Paul Rée (1849-1901), intitulado A origem das impressões morais. Neste livro, afirma Nietzsche, há um tipo contrário e perverso de hipótese genealógica, que o atraiu com a força que tem tudo o

\footnotetext{
18 Escreve Nietzsche: "Era isso o que exigia meu "a priori" de mim? Aquele novo e imoral, pelo menos imoralista "a priori", e o "imperativo categórico" que nele falava, tão antikantiano, tão enigmático, ao qual desde então tenho dado atenção, e mais que atenção?... (1998, p. 9, grifos do filósofo. Genealogia da Moral, "Prólogo", 3)". 19 Genealogia da Moral, "Prólogo", 3.
} 
que é contrário e antípoda. Nada que Nietzsche até então havia lido lhe causou tamanha reprovação, "sentença por sentença, conclusão por conclusão". Todavia, como convém ao espírito positivo - assenta o filósofo - não houve, neste processo de trabalho com o livro de Rée, quaisquer traços de irritação ou impaciência; não houve também qualquer pretensão em refutar as idéias do autor do "livro sagaz", mas sim uma tentativa de substituir o improvável pelo que é mais provável ou, eventualmente, substituir um erro por outro. Foi partindo, pois, deste impulso que Nietzsche confessa ter apresentado pela primeira vez as "hipóteses sobre origens" a que se dedicam as três dissertações que compõem a obra Genealogia da Moral. Tudo foi feito até então de maneira canhestra, sem liberdade, desprovido de uma linguagem própria para tais coisas, com diversas recaídas e hesitações. Na sequiência destas afirmações, Nietzsche solicita ao leitor que confira passagens específicas de algumas de suas obras anteriores. Em Humano Demasiado Humano, Nietzsche pede consulta aos parágrafos 45 (sobre a dupla história do bem e do mal), 136 (sobre valor e origem da moral ascética), 96, 99 e, do volume II $^{20}$, parágrafo 89 (sobre a moralidade do costume). Ademais, Nietzsche invoca a leitura do mesmo Humano Demasiado Humano, parágrafo 92, de $O$ Andarilho, 26; Aurora 112 (sobre a origem da justiça como um acerto entre poderosos mais ou menos iguais); e, finalmente, a leitura de $O$ Andarilho, parágrafos 22 e 33 (sobre a origem do castigo) ${ }^{21}$.

No quinto item, Nietzsche passa a afirmar que mais do que revolver hipóteses sobre a origem da moral (o que havia de lhe servir de meio, entre muitos, em vista de uma finalidade), interessava-lhe precisamente estudar o valor da moral. Para tanto, o filósofo havia de se defrontar com seu grande mestre Schopenhauer (contra quem o livro de Rée também se destinava). Cabia, pois, investigar, o valor do não-egoísmo, dos instintos como os de abnegação, compaixão e sacrifício que justamente Schopenhauer havia feito o elogio, a divinização e a idealização de forma tão duradoura e constante que todos estes instintos tornaram-se valores em si, sobre os quais o seu mestre havia dito "não" a si mesmo e à vida. Nietzsche confessa ter tirado

20 O livro Humano Demasiado Humano foi publicado em 1878.

21 É interessante notar que Nietzsche não cita Além do Bem e do Mal, obra que tem, segundo ele, complemento e clarificação na Genealogia da Moral. 
disso uma desconfiança ${ }^{22}$ cada vez mais radical, percebendo aí o "grande perigo para a humanidade", o "cansaço que olha para trás", a vontade voltando-se contra a vida. Nietzsche então compreendera a moral da compaixão se alastrando e capturando até mesmo os filósofos, notando que a moderna predileção e superestimação da compaixão não existiam antigamente, pois justamente sobre o não-valor da compaixão os filósofos mais antigos estavam até então de acordo; é o caso, exemplifica Nietzsche, de Platão, Espinosa, La Rochefoucauld e Kant.

O sexto item parte da constatação de que, embora à primeira vista este problema sobre o valor da compaixão pareça ser uma questão isolada, quem se atenta neste ponto e aprende a questionar, experimentará (como o próprio autor) a abertura de uma grande perspectiva, fazendo emergir uma nova exigência: uma crítica dos valores morais, em que o próprio valor desses valores seja questionado. Para que tal finalidade seja atingida, Nietzsche afirma a necessidade de um conhecimento das condições e circunstâncias nas quais os valores nasceram, desenvolveram-se e modificaram-se: um tal conhecimento, arremata o autor, como jamais existiu ou foi desejado. Sempre, afirma o filósofo, o valor destes valores foi tomado como dado e efetivo, além de questionamentos. Jamais se questionou o fato de atribuir àquilo que é "bom" valor mais elevado do que àquilo que é "mau"23, esquecendo-se de que pudesse haver talvez um sintoma de regressão, de perigo, de envenenamento através do qual se vivesse o presente como que às custas do futuro. Assim, a moral seria - segundo Nietzsche - a culpada pelo fato de que não se alcance nunca o "supremo brilho" e a "potência do tipo homem". Habitaria, pois, na moral, "o perigo entre os perigos".

Dando início ao penúltimo item, o sétimo do "Prólogo", Nietzsche revela que desde que tal perspectiva se abriu, ele buscou sujeitos ousados e doutos, para os quais ainda hoje olha e, então, apresenta seu objetivo: “per-

\footnotetext{
22 A respeito da presença da palavra "desconfiança" em Nietzsche, torna-se elucidativo visitar Nietzsche, 2000a, p. 7. Humano Demasiado Humano, "Prólogo", 1 - sobre a suspeita. "De fato, eu mesmo não acredito que alguém, alguma vez, tenha olhado para o mundo com mais profunda suspeita, e não apenas como eventual advogado do Diabo, mas também, falando teologicamente, como inimigo e acusador de Deus; [...]".

23 Este valor mais elevado atribuído ao "bom" que ao "mau" deve ser entendido, segundo Nietzsche, a partir dos critérios de utilidade, promoção etc.
} 
correr a imensa, longínqua e recôndita região da moral", mas trata-se da moral realmente existente, que realmente foi vivida, abordada com perguntas novas e novos olhos. Entre estes sujeitos para os quais Nietzsche olhou e ainda olha, encontra-se o Dr. Rée. Não obstante, o filósofo alerta que isso aconteceu "por não duvidar que a natureza mesma das suas questões o levaria a métodos mais corretos para alcançar as respostas". Pergunta-se Nietzsche:

Teria me enganado nisso? Meu desejo, em todo caso, era dar a um olhar tão agudo e imparcial uma direção melhor, a direção da efetiva história da moral, prevenindo-a a tempo contra essas hipóteses inglesas que se perdem no azul (Nietzsche, 1998, p. 13) ${ }^{24}$.

Contra tais hipóteses que se perdem no azul, Nietzsche oferece a cor cinza, bem mais importante para um genealogista da moral, que remete aos documentos, ao que é "efetivamente constatável", "realmente existido" ou, em resumo, "a longa, quase indecifrável escrita hieroglífica do passado moral humano". Contrariando ainda mais a perspectiva de Paul Rée, Nietzsche afirma nada existir que mais compense ser levado a sério, sendo sua recompensa poder talvez no futuro levá-las na brincadeira e na jovialidade, pois esta última (nas palavras de Nietzsche, a "gaia ciência") é uma recompensa por uma longa seriedade que não é para todos.

No dia, porém, em que com todo coração dissermos: 'avante! também nossa velha moral é coisa de comédia!' - teremos descoberto novas intrigas e possibilidades para o drama dionisíaco do 'Destino da Alma'. (Nietzsche, 1998, p. 14)

O oitavo item, que encerra o "Prólogo" de Genealogia da Moral, contém, como a maior parte dos prólogos nietzscheanos, advertências sobre a leitura livro que está na iminência de começar. Ele se inicia com uma ressalva de Nietzsche sobre uma possível incompreensão do livro ou uma pos-

24 Genealogia da Moral, "Prólogo", 7. 
sível dissonância aos ouvidos do leitor. Neste sentido, o filósofo afirma que, em caso de incompreensão da obra, a culpa não será dele necessariamente, uma vez que ela é suficientemente transparente, supondo que o leitor tenha apreciado suas obras anteriores com uma certa "aplicação de leitura", pois confessa Nietzsche - seus livros não são fáceis. Nietzsche trata, por exemplo, da leitura de Assim Falou Zaratustra... que só pode gabar-se de tê-lo conhecido aquele que foi "profundamente ferido e profundamente encantado por cada palavra sua (Nietzsche, 1998, p. 14)"25. Posteriormente, o filósofo toma como problema a forma aforística que utiliza em alguns dos seus escritos e que não vinha obtendo a suficiente importância. Para Nietzsche, um aforismo não obteve ainda sua decifração ao ser meramente lido. Após sua leitura deve-se iniciar sua interpretação, para a qual exige-se a "arte da interpretação". O que Nietzsche entende por interpretação, tem um exemplo na terceira dissertação da Genealogia da Moral, que é antecedida por um aforismo do qual ela consiste justamente no comentário. O pré-requisito postulado por Nietzsche para realizar a leitura como arte é aquilo que - em seus dias - estava justamente sendo perdido e que, portanto, exigiria um certo tempo para que suas obras fossem legíveis: trata-se do "ruminar", para o qual é preciso ser não um homem moderno, mas quase uma vaca.

\section{Breve análise do "Prólogo": Nietzsche voltando-se para si mesmo}

Inúmeras questões habitam, ora declaradamente, ora de forma latente, o "Prólogo" anteriormente apresentado, de modo que seria talvez necessário não somente um amplo ensaio para esgotá-lo, mas alguns grossos volumes de comentários. Não obstante, conforme expresso no início deste trabalho, a iniciativa da apresentação acima exposta teve somente como escopo evidenciar ao leitor a complexidade do texto nietzscheano e a imensa profundidade das questões por ele suscitadas.

A partir deste ponto, será realizada a análise do texto aqui em questão, visando notar como Nietzsche fora especializando sua questão sobre a

25 Genealogia da Moral, "Prólogo", 8.

(C) Filosofia e Educação (Online), ISSN 1984-9605 - Revista Digital do Paideia 132

Volume 1, Número Especial de lançamento, Outubro de 2009 
origem dos valores morais, desde os treze anos até o momento em que redigira a Genealogia da Moral.

Como o primeiro item do "Prólogo" dispõe uma introdução geral ao estudo da genealogia da moral (não havendo ali qualquer menção específica sobre si mesmo), o problema da primeira formulação nietzscheana acerca da origem dos valores morais é iniciado logo no começo do segundo item, quando Nietzsche afirma que a primeira expressão de seus pensamentos sobre a origem dos nossos preconceitos morais deu-se em sua obra Humano Demasiado Humano.

Todavia, conquanto a expressão primeira de seus pensamentos sobre a moral tenha se iniciado em 1878, Nietzsche afirma que um escrúpulo relativo à moral (seu a priori) já o habitava e o fizera responder, aos treze a$\operatorname{nos}^{26}$, à questão: “de onde se originam verdadeiramente nosso bem e nosso mal?". Nesta época (a época em que, segundo Nietzsche em referência a Goethe, a criança divide-se entre os brinquedos e Deus), o filósofo realizou sua primeira brincadeira literária e seu primeiro exercício filosófico, respondendo àquela pergunta com a afirmação de que Deus era o Pai do mal. Estas foram, respectivamente, a primeira questão nietzscheana sobre a moral e a sua primeira resposta.

Inconformado com o que fizera de seu a priori, o filósofo revela que por fortuna, ele logo aprendeu a separar o preconceito teológico do preconceito moral. Esta separação é de profunda importância para o conhecimento da formulação do problema da moral em Nietzsche, pois evidencia uma virada absoluta em sua concepção a respeito deste problema, principalmente quando ele afirma que com esta separação deixou de procurar a origem do mal por "trás do mundo", isto é, pela transcendência. É interessante notar que Nietzsche responsabiliza a sorte pelo aprendizado da distinção entre os dois preconceitos, não havendo - até aqui - qualquer menção a um episódio mais objetivo, nem qualquer alusão a um fato concreto que o teria levado a essa distinção entre os preconceitos. O filósofo limita-se a indicar que a distinção entre os dois preconceitos se deu em seu espírito por obra de um feliz ${ }^{26}$ Tendo Nietzsche nascido em 1844, aos treze anos Nietzsche vivia o ano de 1857, vinte e
um anos antes da produção de Humano Demasiado Humano.

(C) Filosofia e Educação (Online), ISSN 1984-9605 - Revista Digital do Paideia 133

Volume 1, Número Especial de lançamento, Outubro de 2009 
acaso (isto é, sorte ou fortuna). Cabe, evidentemente, tentar compreender um pouco melhor o que Nietzsche entende por sorte, fortuna e acaso.

Em Aurora, 4, 363, o filósofo oferece aos seus leitores as seguintes palavras sobre o acaso: "O essencial, em toda invenção, é feito pelo acaso, mas a maioria dos homens não encontra esse acaso". (Nietzsche, 2004, p. 205)

Parece ser pertinente, portanto, pensar que este feliz acaso (raramente encontrado entre os homens) seria da mesma natureza que aquele tratado por Nietzsche ao se referir à separação dos dois preconceitos. Entretanto, algo mais revelador ainda para a compreensão do que entende Nietzsche por sorte e fortuna é outra passagem de Aurora $(5,458)$, em que o filósofo registra (sobre a "grande sorte") as seguintes palavras: "[...] algo muito raro, mas encantador: uma pessoa de intelecto finamente constituído, que tem o caráter, as inclinações e também as vivências apropriadas a esse intelecto". (Nietszche, 2004, p. 235, grifos de Nietzsche) ${ }^{27}$

Com esta afirmação, compreende-se que a sorte de que trata Nietzsche, não é algo meramente fortuito, mas, muito pelo contrário, algo que se traduz em um intelecto finamente constituído, possuidor de caráter, de inclinações e (o que os grifos do autor reforçam) possuidor das vivências a ele apropriadas $^{28}$.

Nota-se aqui, retornando ao texto do "Prólogo", que há uma ruptura com a questão outrora formulada e, considerando que o abandono dessa antiga problematização se deu pela via da fortuna, o que leva o filósofo a realizar uma segunda série de questões sobre a moral é, como fora anteriormente apontado, uma certa educação histórica e filológica, acrescida de um senso inato e seletivo para questões psicológicas, que transformou o seu problema em outro.

Que uma educação filológica tenha possibilitado a elaboração de novas perguntas, constata-se logo na "Primeira dissertação" de Genealogia

\footnotetext{
${ }^{27}$ Vê-se que a pouca incidência da sorte ou do acaso nos homens é mencionada igualmente nas duas últimas transcrições de Nietzsche feitas aqui.

${ }^{28}$ Não parece exagero supor que as vivências para as quais, segundo afirma Nietzsche no primeiro item do "Prólogo", os homens não têm tempo sejam exatamente essas que compõe o espírito possuidor da "grande sorte".
} 
da Moral, 4, quando Nietzsche confessa, a despeito de outras explicações para a origem da moral que julga como erradas (Nietszche, 1998, p. 20. Genealogia da Moral, 1, 3), que o caminho correto fora-lhe dado quando ele considerou a seguinte questão: “[...] que significam, do ponto de vista etimológico, as designações para 'bom' cunhadas pelas diversas línguas? (Nietszche, 1998 , p. 20$)^{29}$

O filósofo descobriu que essas designações remetem a uma e mesma transformação conceitual, qual seja, a do sentido social dos termos "nobre" e "aristocrático" que, basicamente, deram origem ao "bom". Dando seqüência à leitura da "Primeira Dissertação", constata-se que Nietzsche (nos parágrafos 4 e 5) aplica um tratamento propriamente filológico ao tema da moral, confirmando o que fora anunciado no "Prólogo".

É possível ainda, recorrendo a dois parágrafos anteriores da "Primeira Dissertação" entender porque Nietzsche também menciona, em sua vida, a presença diferencial de uma "educação histórica": é justamente a falta de um espírito histórico que Nietzsche critica nos historiadores ou genealogistas da moral de seu tempo:

[...] todo o respeito, portanto, aos bons espíritos que acaso habitem esses historiadores da moral! Mas infelizmente é certo que lhes falta o próprio espírito histórico, que foi abandonado precisamente pelos bons espíritos da história! (Nietzsche, 1998, p. 18. Genealogia da Moral, 1, 2)

Nietzsche vai, desta forma, engendrando, logo no início de sua "Primeira Dissertação", uma profunda reflexão que parte da crítica geral aos genealogistas ingleses $(\S 1)$ e da crítica à falta de espírito histórico apresentada por eles ( $\$ 2$ e 33$)$. Posteriormente, Nietzsche apresenta seus questionamentos filológicos e o resultados de sua investigação sobre a origem dos termos "bom" e "ruim" ( $\$ 4$ e $§ 5)$; paulatinamente, vai elaborando análises diversas a partir dos dados da investigação filológica.

${ }^{29}$ Genealogia da Moral, $1,4$. 
Após colocar suas novas questões acerca da moral ${ }^{30}$, Nietzsche afirma que o impulso inicial para publicar suas hipótese sobre "procedência da moral" veio a partir da publicação do já citado livro de Rée para o qual, ainda que sem irritação ou falta de paciência, ele disse "não" a cada uma de suas sentenças.

Para Nietzsche, então, já não cabia mais revolver hipóteses e sim procurar o valor da moral que dele exigia um confronto com o mestre Schopenhauer, filósofo que fez os valores se tornarem valores em si, sustentando aí uma profunda negação da vida e de si. Percebendo a filosofia de Schopenhauer como sintoma de cansaço e de incidência da vontade contra a vida, bem como algo muito recente na história da filosofia, Nietzsche impõe, segundo suas próprias palavras, "por fim”, uma nova exigência, que pode ser entendida também como uma nova tarefa para a filosofia, já mencionada aqui: "estabelecer a crítica dos valores morais, colocando o próprio valor destes valores em questão”.

\section{Considerações sobre o "Prólogo" da Genealogia da Moral}

Após a apresentação do "Prólogo" e sua breve análise aqui empreendida fica patente que Nietzsche realiza neste espaço uma síntese do processo de construção de um problema seu: o problema da moral. O filósofo volta seu olhar para sua própria vida, desde a infância.

O percurso poderia ser sumarizado em cinco momentos:

1) Quando, aos trezes anos, a questão nietzscheana era meramente a origem do bem e do mal;

2) Quando o filósofo separa o preconceito teológico do preconceito moral e uma educação histórica e filológica somada a um senso seletivo em questões de psicologia transforma seu problema;

\footnotetext{
30 Estas novas questões são, conforme já foi aqui apresentado, as seguintes: "sob que condições o homem inventou para si os juízos de valor 'bem' e 'mal'? e que valor têm eles? Eles obstruíram ou promoveram até agora o crescimento do homem? São indício de miséria, empobrecimento, degeneração da vida? Ou, ao contrário, revela-se neles a plenitude, a força, a vontade da vida, sua coragem, sua certeza, seu futuro? (Nietzsche, 1998, p. 9. Genealogia da Moral, "Prólogo", 3)"
} 
3) Quando houve a publicação do livro de Rée, em 1887, que gerou em Nietzsche o impulso pela divulgação de suas hipóteses;

4) Quando a questão se torna o valor da moral, que impõe o confronto com o mestre (Schopenhauer);

5) Quando, "por fim”, Nietzsche formula a nova exigência: questionar o valor dos valores;

O processo nietzscheano de formulação da questão sobre a moral, conforme se percebe, cumpre em certa medida o percurso das "três transformações" do espírito, descrito em Assim Falou Zaratustra... (Nietzsche, 1977). Em primeiro lugar, como um camelo, Nietzsche coletou hipóteses, estudou, carregou o peso das leituras e pesquisas. Em segundo lugar, como o leão, depois de ter ouvido as especulações morais dos genealogistas despidos do espírito histórico, disse "não" e impôs sua vontade contra aquilo que lhe impuseram como dever. Finalmente, em terceiro lugar, ele passou a publicar seus escritos, como uma criança, simbolizando um novo começo, sob a perspectiva da afirmação.

A mudança do espírito em camelo (correspondente aos momentos 1 e 2) divide-se entre a atribuição da paternidade do mal a Deus e a ruptura entre preconceito teológico e o moral, transformando o problema em virtude da educação e de um senso psicológico. Esta mudança em camelo é seguida pela mudança do espírito em leão (correspondente ao momento 3). É possível perceber que mesmo negando o livro de Rée, Nietzsche alerta que trabalhava como convém ao espírito positivo: sem refutações, mas com a intenção de substituir o improvável pelo mais provável (ou substituir um erro por outro erro), o que em certa medida já indica a afirmação da criança, correspondente ao momento 5 .

Não obstante, o quarto momento não foi considerado. Nele, com efeito, Nietzsche alude ao confronto com o mestre. Tendo este confronto em vista, é impossível não lembrar da Terceira Consideração Extemporânea, intitulada "Schopenhauer como Educador" e, diante dela, perguntar: por que entre o momento 3 e o momento 5 há Schopenhauer figurando como intermédio ao novo recomeçar? A pergunta é pertinente, porque Nietzsche mesmo afirmara que Schopenhauer havia sido aquele filósofo que dourou, divi- 
nizou e idealizou alguns valores tornando-os valores em si, além de todo questionamento.

Recorrendo à Extemporânea acima citada, uma resposta se apresenta, qual seja:

Certamente, existem outros meios de se encontrar a si mesmo, de escapar do aturdimento no qual nos colocamos habitualmente, como envoltos numa nuvem sombria, mas não conheço coisa melhor do que lembrar dos nossos mestres e educadores. É por isso que vou lembrar hoje o nome do único professor, o único mestre de quem posso me orgulhar, Arthur Schopenhauer, para só me lembrar de outros mais tarde. (Nietzsche, 2003, p. 142) ${ }^{31}$

Através do excerto acima, tirado do texto de Nietzsche, conclui-se que Schopenhauer é tomado como o melhor meio para encontrar-se a si mesmo e é justamente como "meio" que este filósofo pessimista aparece no momento 4 da formulação do problema da moral. Este momento é aquele que prepara a chegada a si mesmo e, "por fim”, à enunciação da nova exigência. É permitido, neste sentido, excogitar que além do livro de Rée, também tenha sido Schopenhauer o dragão das "três transformações" de Assim falou Zaratustra..., aquele que tem escamas que evocam o "tu deves" e para o qual o leão responde "eu quero".

Foi possível, enfim, apresentar os sentidos pelos quais a educação emerge no "Prólogo" da Genealogia da Moral: em primeiro lugar, como processo de formulação de um problema que acompanha a vida de Nietzsche desde os treze anos até a sua maturidade; em segundo lugar, como educação histórica e filológica que permitiu uma transformação do problema acerca da moral e, finalmente, em terceiro lugar, pela figura de Schopenhauer como educador. Este percurso nietzscheano sugere, em suas pegadas, a definição de uma tarefa para a pedagogia.

31 III Considerações Extemporâneas: "Schopenhauer como Educador", I. 
Conclusão: esboçando a definição de uma tarefa para a Pedagogia

Como foi inicialmente esclarecido ao leitor, este trabalho não tem por objetivo empreender, para a Pedagogia, qualquer tarefa que seja. Muito menos, trata-se de definir esta tarefa, mas simplesmente de prepará-la. O questionamento, porém, está feito e aquilo que, em primeiro lugar nos leva a fazê-lo é o "Prólogo" da Genealogia da Moral. A questão é a seguinte: da mesma forma que toda atividade humana está impregnada pela moralidade, em que medida a atividade pedagógica também não está sujeita à moral e, enquanto tal, não se encontra definida por pressupostos de obediência cega a regras e costumes?

Todavia, cabe esclarecer o que precisamente significa "esboçar a definição de uma tarefa para a Pedagogia”.

Esboço é aqui tomado, essencialmente, como preparação; por ser preparação, não pode, pois, concluir nada acerca do que somente prepara, mas pode (e deve) pôr em questão, iniciar o questionamento, colocar o ponto de interrogação sobre aquilo que, até então, não foi objeto de inquirição senão de modo despercebido.

Definição, por sua vez, admite, neste contexto, dois sentidos: o primeiro é o de definição de um singular, isto é, "definição de" uma tarefa em especial, distinta de outras tarefas; o segundo é o de resolução ou decisão por uma ocupação, isto é, "resolução por" uma tarefa. Trata-se, pois, de definir uma tarefa e se resolver por enfrentá-la.

Portanto, "esboçar para a definição" significa preparar a definição $d a$ tarefa e pela tarefa.

Tarefa, finalmente, significa "ocupação" e o fato de ser precedida pelo pronome indefinido "uma", justifica a necessidade dos termos antecedentes (a necessidade de "esboço" para sua "definição" de e por "uma tarefa"). Trata-se da tarefa de colocar tudo em jogo em nome do enfrentamento da questão que nossa leitura de Nietzsche coloca à Pedagogia e que foi enunciada acima.

Diante da questão proposta, resta conceber que a "definição de" uma tarefa deve vir em consonância com a "definição por" uma tarefa; sen- 
do assim, não é dado somente a um pesquisador ou a um estudioso da Pedagogia empreender a definição, embora lhe seja perfeitamente possível esboçá-la e interrogá-la a partir, por exemplo, da retomada do "Prólogo" de Nietzsche. Lá se encontram reunidos todos os elementos necessários de um esboço, expressos em cinco momentos: (1) insistir em uma questão inicial; (2) afastar o preconceito teológico do preconceito moral, atuando com uma educação verdadeiramente histórica e, tanto quanto possível, também filológica; (3) criar meios através dos quais as hipóteses da Pedagogia sobre a moral observada em si mesma sejam divulgadas, criando o ambiente necessário para a execução da tarefa; (4) rivalizar contra os mestres ${ }^{32} \mathrm{e}$, finalmente, (5) colocar-se a cada passo uma nova exigência, um constante "por em questão".

A Pedagogia precisa, pois, sentir a necessidade interna de pôr em questão a sua própria moral, isto é, não deixar que a moral que lhe perpassa muitas vezes em silêncio permaneça além do questionamento. Nietzsche, nos diversos momentos que compõem seu percurso relativo à pergunta pela origem da moral (os quais aqui foram sintetizados em cinco) não se importou em mudar constantemente seu problema; ele fez deste constante "mudar", um movimento necessário para uma genealogia da moral ${ }^{33}$.

Na composição que definirá uma tarefa para pedagogia cabe, principalmente aos que têm a jovialidade, semear a suspeita nos grandes educadores e nas suas grandes lições; cabe deixá-los com a dignidade da suspeita. Todavia, parece haver na Pedagogia atual - em linhas gerais - uma presença apenas espectral dos grandes mestres, uma vez que eles permanecem presentes, mas sem a leitura atenta dos seus textos; isso impede que a Pedagogia possa definir precisamente o seu rival.

\footnotetext{
32 Deve-se afastar daqui toda interpretação que afirme que esta perspectiva é revanchista ou inamistosa; pelo contrário, trata-se de rivalizar, o que se faz para que haja um debate teórico público e consistente.

33 Nietzsche afirma insistentemente a transformação e especialização de seu problema no item 3 do "Prólogo", diz ele: "[...] em breve transformou meu problema em outro: sob que condições o homem..." e "[...] especializei meu problema, das respostas nasceram novas perguntas, indagações, suposições..." (Nietzche, 1998, p. 9. Genealogia da Moral, "Prólogo", 3). Este movimento só pára quando ele "por fim" chega à nova exigência, que determina a composição das três dissertações do livro.
} 
Não se pode confundir esta tarefa da Pedagogia com o estudo das imbricações entre educação e moralidade, ocupação que ultimamente vem cabendo - de maneira manifesta - somente aos psicólogos da educação; a eles, inclusive com justeza, não interessa a moral na Pedagogia, pois este é um problema da Pedagogia e, portanto, convém apenas àqueles que passaram pela formação em Pedagogia.

Afirmar, porém, que esta tarefa é "tarefa para a Pedagogia", não significa decretar que as demais disciplinas do conhecimento humano não tenham questões morais interiores a resolver. Isso significa, pelo contrário, que a moral aparece para a Pedagogia de maneira diferenciada e específica em comparação com as demais ciências. Por ser assunto para um novo estudo, não se sabe ainda ao certo de que natureza é essa especificidade. O que se vê, por toda parte, é somente seu o primeiro sintoma, qual seja, a capacidade de evitar para si mesma, com uma virulência incrível, a questão sobre a moral em seu interior.

Não é de se admirar que alguns pedagogos e algumas pedagogas não entendam prontamente a finalidade para a qual se faz a questão; em alguns deles, ela não está nem ao menos perto de incomodar, tão grandes e profundas são as raízes desta moralidade ainda impensada.

\section{Referências bibliográficas}

DIAS, R. Nietžsche Educador. São Paulo: Scipione, 1991.

NIETZSCHE, F. Assim Falou Zaratustra: um livro para todos e para ninguém. Rio de Janeiro: Editora Civilização Brasileira S.A., 1977.

1994.

. Crepuisculo de los Ídolos - o Como se Filosofa con el Martillo. Madrid: Alianza,

. Ecce Homo - Como Alguém se Torna o que É. São Paulo: Cia. das Letras, 1995.

. Genealogia da Moral - Uma Polêmica. São Paulo: Cia. das Letras, 1998.

. Humano Demasiado Humano - Um Livro para Espíritos Livres. São Paulo:

Cia. das Letras, 2000a. 2000b.

Cinco Prefácios para Cinco Livros não Escritos. Rio de Janeiro: Sete Letras, . A Gaia Ciência. São Paulo: CIA das Letras, 2001.

“'III Consideração Intempestiva: Schopenhauer Educador”.In: Escritos sobre Educaşão. Rio de Janeiro: PUC-RJ; São Paulo: Loyola, 2003, 227p, pp. 138222. 
2004.

Aurora - Reflexões sobre os preconceitos Morais. São Paulo: Cia. das Letras,

(C) Filosofia e Educação (Online), ISSN 1984-9605 - Revista Digital do Paideia

Volume 1, Número Especial de lançamento, Outubro de 2009 